3. Tiranti V, Carrara F, Confalonieri P, et al. A novel mutation (8342G$>\mathrm{A}$ ) in the mitochondrial tRNA(Lys) gene associated with progressive external ophthalmoplegia and myoclonus. Neuromuscul Disord 1999;9: $66-71$.

4. Valanne L, Ketonen L, Majander A, et al. Neuroradiologic findings in children with mitochondrial disorders. AJNR Am J Neuroradiol 1998; 19:369-377.

5. Montagna P, Gallassi R, Medori R, et al. MELAS syndrome: characteristic migrainous and epileptic features and maternal transmission. Neurology 1988;38:751-754.

6. Carelli V, Sadun AA. Optic neuropathy in LHON and Leigh syndrome. Ophthalmology 2001;108:1172-1173.
7. Pulkes T, Eunson L, Patterson V, et al. The mitochondrial DNA G13513A transition in ND5 is associated with a LHON/MELAS overlap syndrome and may be a frequent cause of MELAS. Ann Neurol 1999;46:916-919.

8. Liolitsa D, Rahman S, Benton S, et al. Is the mitochondrial complex I ND5 gene a hot-spot for MELAS causing mutations? Ann Neurol 2003;53:128-132.

9. Uziel G, Moroni I, Lamantea E, et al. Mitochondrial disease associated with the T8993G mutation of the mitochondrial ATPase 6 gene: a clinical, biochemical, and molecular study in six families. J Neurol Neurosurg Psychiatry 1997;63:16-22.

10. Sazanov LA, Walker JE. Cryo-electron crystallography of two subcomplexes of bovine complex I reveals the relationship between the membrane and peripheral arms. J Mol Biol 2000;302:455-464.
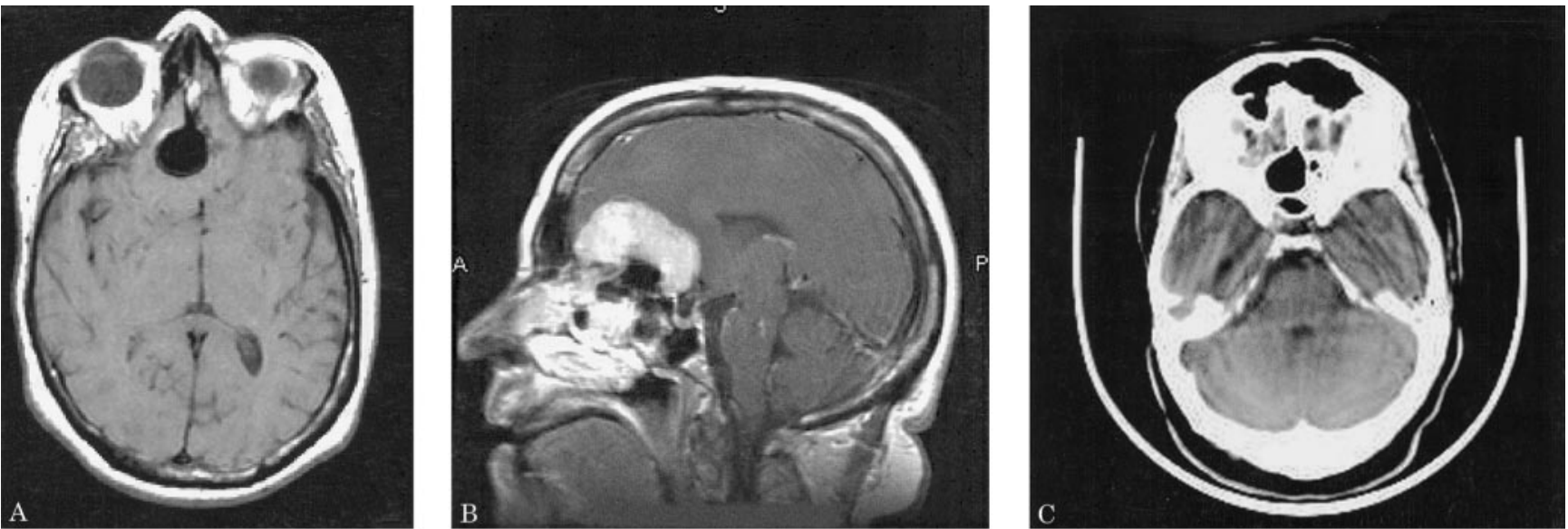

Figure. (A) Enlarged, air-filled ethmoid sinus extending into an isointense intracranial mass on T1-weighted MRI, which enhances uniformly on contrast agent administration (B). (C) Axial CT shows expansion of sinus beyond its normal boundaries into the meningioma, where the plate of bone lining the pneumosinus dilatans is preserved.

\section{Meningioma with pneumosinus dilatans}

Anne Mai, MD; John Karis, MD; and

Kumaraswamy Sivakumar, MD

A 67-year-old woman presented with an episode of confusion. A complex partial seizure was suspected. Pneumosinus dilatans

From the Division of Neurology, Barrow Neurological Institute, St. Joseph's Hospital and Medical Center, Phoenix, AZ.

Received December 6, 2002. Accepted in final form January 31, 2003.

Address correspondence and reprint requests to Dr. K. Sivakumar, Barrow Neurological Institute, 240 W. Thomas Rd., Phoenix, AZ 85013; e-mail ksivakumar@chw.edu
(PSD) associated with a cribriform plate meningioma was found on MRI ( figure). Histology revealed a meningothelial meningioma.

An abnormally expanded, air-filled paranasal sinus best describes PSD. It can be associated with meningiomas or arachnoid cysts. The detection of a PSD is useful in identifying a cerebral mass as a meningioma, especially when it appears intrinsic to the brain. ${ }^{1}$ The presence of sphenoid PSD in patients with blindness helped identify optic nerve sheath meningiomas in the era when $\mathrm{CT}$ and MRI were not available. ${ }^{2}$

1. Miller NR, Golnik KC, Zeidman SM, North RB. Pneumosinus dilatans: a sign of intracranial meningioma. Surg Neurol 1996;46:471-474.

2. Hirst LW, Miller NR, Hodges FJ III, Corbett JJ, Thompson S. Sphenoid pneumosinus dilatans. A sign of meningioma originating in the optic canal. Neuroradiology 1982;22:207-210. 


\title{
Neurology
}

\author{
Meningioma with pneumosinus dilatans \\ Anne Mai, John Karis and Kumaraswamy Sivakumar \\ Neurology 2003;60;1861 \\ DOI 10.1212/01.WNL.0000064170.08465.3B
}

This information is current as of June 10, 2003

\section{Updated Information \& Services}

References

Citations

Subspecialty Collections

Permissions \& Licensing

Reprints including high resolution figures, can be found at: http://n.neurology.org/content/60/11/1861.full

This article cites 2 articles, 0 of which you can access for free at: http://n.neurology.org/content/60/11/1861.full\#ref-list-1

This article has been cited by 3 HighWire-hosted articles: http://n.neurology.org/content/60/11/1861.full\#\#otherarticles

This article, along with others on similar topics, appears in the following collection(s):

\section{All Imaging}

http://n.neurology.org/cgi/collection/all_imaging

\section{MRI}

http://n.neurology.org/cgi/collection/mri

Primary brain tumor

http://n.neurology.org/cgi/collection/primary_brain_tumor

Information about reproducing this article in parts (figures,tables) or in its entirety can be found online at:

http://www.neurology.org/about/about_the_journal\#permissions

Information about ordering reprints can be found online: http://n.neurology.org/subscribers/advertise

Neurology ${ }^{\circledR}$ is the official journal of the American Academy of Neurology. Published continuously since 1951, it is now a weekly with 48 issues per year. Copyright . All rights reserved. Print ISSN: 0028-3878. Online ISSN: 1526-632X.

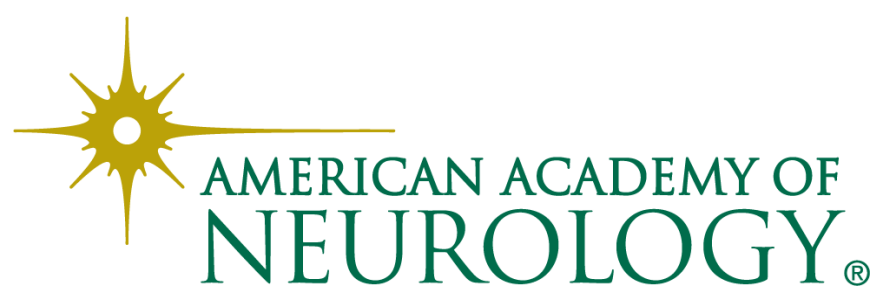

